\title{
Socio-Cultural Determinacy of Human Loneliness
}

\author{
Igor A. Belyaev and Maksim N. Lyashchenko* \\ Orenburg State University \\ Orenburg, Russian Federation
}

Received 19.04.2019, received in revised form 04.08.2020, accepted 12.08.2020

\begin{abstract}
The article justifies the socio-cultural determinacy of human loneliness. Philosophical and cultural discourse has been developing through synthesis of heterogeneous and diverse theoretical positions. The formula by Karl Marx, which shows that the unity of human relationship with nature is determined by the unity of relations between individuals, was of paramount importance for the study. The existence of society and community was considered as two dialectically interrelated forms of sociality, the lack of coordination between which leads to the emergence of human loneliness. The statement of the synergetic paradigm on the non-equilibrium nature of social structures has become heuristically valuable for conducting the research. Relying on the information about age-related peculiarities of human development based on the concept of E. Erickson, allowed to obtain the desired result. The philosophical and cultural interpretation of these and related provisions made it possible to establish that loneliness can be recognised as a consequence of the decreasing community level in the course of interaction between individuals and the impossibility of maintaining its high level, which is expressed in the Meeting of the Self and the Significant Other (one's own Other). It was revealed that: community with a Significant Other is a measure of actualising the integrity and wholeness of the person's being; the more diverse and wider the area of Significant Others, the more harmonious the person's being; the person who has broadened the horizons of the Meeting as fully as possible is truly authentic; an increase in the depth of integration of the person with the processes and phenomena that are natural for each age stage passed, reduces the likelihood of loneliness, and, therefore, makes them more rooted in the existence.
\end{abstract}

Keywords: loneliness, culture, society, community, Meeting, human integrity.

Research area: philosophy.

Citation: Belyaev, I.A., Lyashchenko, M.N. (2020). Socio-cultural determinacy of human loneliness. J. Sib. Fed. Univ. Humanit. Soc. Sci., 13(8), 1264-1274 DOI: 10.17516/1997-1370-0640.

\footnotetext{
(C) Siberian Federal University. All rights reserved

* Corresponding author E-mail address: igorbelyaev@list.ru, megamax82@rambler.ru ORCID: 0000-0003-4072-2342 (Belyaev); 0000-0001-7193-5610 (Lyashchenko)
} 


\section{Introduction}

After the collapse of the USSR, Russian researchers, including philosophers working on cultural and anthropological problems, found themselves in a deep and protracted methodological crisis, first of all, caused by discrediting the previously unambiguously dominant dialectical materialism. The harsh criticism of the Marxist philosophical doctrine that unfolded in the first post-Soviet years, with the simultaneous recognition of its cognitive inconsistency and incompatibility with other approaches and paradigms, made it almost inevitable to abandon it. The variety of Western philosophical approaches and trends that became available in these years has become and still remains the dominant methodological basis for cultural and human studies. Therefore, the philosophical and culture-focused understanding of human loneliness in the context of the teachings of $\mathrm{K}$. Marx with its heuristic value reinforced by the research orientation towards the use of interdisciplinary connections, should deepen the prevailing ideas concerning this phenomenon and contribute to the identification of socio-cultural patterns of its occurrence and existence.

\section{The formula by K. Marx}

A critical analysis of the notions of the human loneliness indeterminacy allows us to assert that loneliness is, first of all, a socially and culturally determined phenomenon with its foundations found in the formation of society as a socio-cultural organism, reproducing, developing and functioning at the level of actively interconnected individuals. Karl Marx wrote, "the social history of people is always only the history of their individual development, whether they are aware of it or not" (Marx, 1962: 402403). Any individual creative and transforming activity is a social activity, which is impossible without the involvement of an individual in relationships with other individuals. Therefore, in this way "man produces man - himself and the other man; ... just as society itself produces man as man, so it is produced by him" (Marx, 1956: 589). It is the analysis of sociality (community with Others) and its forms that, in our opinion, contains the key to understanding the existential being of a person and the phenomena associated with it (including loneliness).

In our theoretical analysis, we first turn to the concept of Karl Marx, the key and constitutive basis of which is a well-known formula: the unity of man's relationship with nature is determined by the unity of relations between individuals. The features of this formula have already been considered more than once (for example, by V.A. Gert, E.S. Il'enkov, M.S. Kagan, B.F. Porshnev and others). Given these circumstances, it makes sense to emphasise the following: all the variables of this formula are interdependent and mutually reinforcing, but the determining (that is, the independent variable) in this scheme is still the relationship of man with man. There is no doubt that changes to the independent variable result in changes to the dependent variable. Thus, the relationship between human and nature is determined precisely by the relationship between individuals, and not vice versa. Moreover, we believe that one of the consequences of changes in relationships between individuals is loneliness. It turns out that the key to successful avoidance of loneliness is maintaining balance (harmony) between the 'variables' of this formula.

Following the formula under discussion, it can be argued that the fundamental human need is to be surrounded by their own kind and have communication with other people. All other spiritual and social needs, for example in self-fulfilment, identity, knowledge, ideals, values, etc. are built on its basis. With a high degree of certainty, it can be argued that a similar point of view was characteristic of Plato, Aristotle, L. Feuerbach, K. Marx, M. Buber, M.M. Bakhtin and other famous thinkers for whom community with the Others, in the words of the same Karl Marx, seemed to be 'the greatest wealth', rightly opposed to the imaginary (material) wealth, which, in reality, is not capable of giving integrity and wholeness to human existence.

\section{Community as the basis for existence of the Meeting}

Representatives of cultural anthropology (in particular, F. Tönnies, K. Levi-Strauss) consider community as a basic and fundamen- 
tal form of sociality, which contributes to the growth of social forms of sociality out of its needs (society, social systems, social institutions) (Levi-Strauss, 1985; Tönnies, 2002). One cannot but agree that community (being with the Significant Other), being a form of sociality, in the spiritual-existential understanding is primary in relation to society as being with the Other. Therefore, it is more desirable for the Self to be with the Significant Other (one's own Other) than with the Other. However, community without society is meaningless and cannot exist, like the Significant Other without the Other. Moreover, the Other potentially conceals one's own Other. A necessary condition for the implementation of all this is the Meeting.

It is noteworthy that these two forms of sociality are interconnected and interdetermined. Mismatch and deharmonisation of relations between them is a condition for the emergence of loneliness and various forms of deviation and addiction. Failures, deformations, damage and restructuring that occur in society will certainly (and usually negatively) affect the integrity and self-identity of the community. Therefore, the harmonious coherence of community and society is a condition that almost completely excludes the likelihood of loneliness and various deviant types of behaviour. However, according to the synergic paradigm, objects existing in the world, in the overwhelming majority of cases, should be recognised as non-equilibrium systems. Thus, according to A.P. Nazaretian, society is a non-equilibrium system, the specificity of which is that structural deformations, disorganisation and destabilisation are inevitable in it; its stability is provided by mediating mechanisms (culture) (Nazaretian, 2012: 62).

Man is, first of all, "directly a natural being, ... suffering, dependent and limited; that is to say, the objects of his impulses exist outside him, as objects independent of him; yet these objects are objects of his need - essential objects, indispensable to the manifestation and confirmation of his essential powers" (Marx, 1956: 631). Having an object outside himself (and it cannot be otherwise, at least according to K. Marx), a person becomes an object for another being, as he seeks to fulfill his essence outside, which conditions the formation of connections between him and other people (Marx , 1956: 632). K. Marx states, "non-objective being is an impossible, absurd being" (Marx, 1956: 632), which basically cannot have a place in existence. Thus, in the process of joint activity, individuals enter into communication, forming a certain type of connection with each other, which becomes "a structure of society" i.e. a system of social relations that determines the activity of an individual, including his communication with other individuals, his inherent states and behavioural strategy (Kagan, 1988).

Mainly, the purpose of society, its structural organisation and institutions is to achieve and maintain community between individuals and ensure its high level - the Meeting, where a person's being acquires spiritual and personal integrity, wholeness and self-identity.

\section{Culture as a prerequisite}

\section{for maintaining community}

\section{and openness between people}

Next, our focus falls on the culture. However, specialists have different understanding of it. Let us list some versions of the concept of this phenomenon that appear in the works of authoritative Russian philosophers. L. N. Kogan, in particular, interprets culture as a process which serves as a framework for the essential forces of man to be formed and fulfilled (Kogan, 1981: 41). M.S. Kagan sees in culture something that produces specific historical forms of communication and ensures their implementation (Kagan, 1988). D.V. Pivovarov believes that culture is the ideal-forming aspect of human life (Pivovarov, 1996: 50). V.S. Stepin understands culture as a 'genetic code' developed by society ensuring the reproduction and development of forms of human life (Kuda idet rossiiskaia..., 2009). Yu.M. Lotman considers culture as a special activity aimed at the reproduction and development of human social being (Lotman, 2002).

Despite all the discrepancies in the above and other theoretically consistent definitions, there is something that unites all of them, serving as their common denominator: culture is the content of the community's vital activity 
(F. Tönnies, K. Levi-Strauss) aimed at hominisation and formation of the necessary qualities for living together, becoming the next mechanism of evolution of human existence after nature (Markov, 2009: 24). Presumably, only when this circumstance is taken into account can one understand why culture:

- produces ideals (traditions, notions, values) not only ensuring the continuity of public behavioural patterns, but also 'contouring' the horizons of man's seeking to go beyond the limits of the present existence;

- guarantees the continuity and duration of human transformative activity, and, accordingly, the continuity between generations, thereby linking the time horizons of the past, present and future into a single whole;

- sets a value-semantic determination, which expresses the relevance of the growth of autonomous and integral individuality to some extent relieving a person from external circumstances and from their own impulses and needs (Gert, 2016: 300); accordingly, culture acts as $a$ kind of measure of spiritual and moral self-improvement of a person and his self-construction as a person;

- is a value-semantic space that binds and connects man, society and nature into a single whole; entering a value-semantic space with a Significant Other through the Meeting allows a person to find integrity, completeness and self-identity of his being; at the same time, culture is the world "between" (M. Buber), connecting and fastening man with other people, man with nature, etc.;

- ensures emergence and development of the dialogue between man and the world; when man enters culture, he becomes its living particle and develops a dialogue with the surrounding world by its means; culture, in its turn, encodes the surrounding world by means of meanings and values, which man in the process decodes, internalises setting new value-semantic horizons (i.e. re-encodes them);

- prepares the entry of a person into the world of people, the Meeting with Significant Others; culture, accordingly, is the only possible way man's existence in a humanised form, in which the spiritual heights of being are available to him, making him free in a prede- termined and acquired integral spiritual and moral image;

- conditions man's disclosure of himself to other people, being together with them, which allows him to feel and realise the spiritual and personal integrity and wholeness of all being.

\section{Sociolisation as a prerequisite \\ for preserving and maintaining \\ the wholeness of community}

At the same time, the spiritual-personal (cultural) human development takes place in various social environments, within the framework of communities, in which specific communication develops and a spiritual space is formed, where he meets a Significant Other (his Other). Initially, the individual is included in the microenvironment formed by family and relatives, then in the macroenvironment society, thereby acquiring participation in the entire social world. The essence of each individual person, which is the result of the entire world history, cannot be separated neither from the essence of previous generations, nor from the essence of his contemporaries, with whom he actually interacts (Marx, 1955: 44-45). In other words, from the very birth, circles of connectedness are formed around an individual, which, in the course of his growing up, spiritual and personal formation, tend to expand and include an increasing number of Significant Others (family members, friends, loved one, people close in spirit, etc. etc.), i.e. all those the individual feels true community with. It must be assumed that this is precisely the Meeting regulated on the basis of L. Feuerbach's anthropological principle, according to which man cannot exist without man, since people are the highest value for each other.

The expansion of the circles of connectedness is, in fact, the expansion of the inner world of a person himself and the inclusion of an increasing number of Others, becoming dominants of his inner world, together with which alone it is possible to gain integrity and feel the fullness of being, i.e. to become truly happy. Community with the Significant Other, in our opinion, expresses the measure of the integrity and wholeness of the person's being. The 
more diverse and wider the area of the person's Significant Others, the more complete, holistic and harmonious his being. An authentic, truly wholesome (Belyaev, 2011: 633-643) is the person who maximally expanded the horizons of the Meeting.

An important condition for a person's Meeting with a Significant Other is his exploration of social (socialisation) and cultural (enculturation) space. It is widely believed that the process of socialisation is aimed mainly at the acquisition of socially significant qualities by an individual that he needs to become a person. In general, this should not be denied. However, the process of socialisation, like the process of enculturation, carries a deeper and more important task: to create from a living organism an integral and authentic person capable of treating humanly everything around him, and, most importantly, his own kind (Il'enkov, 1984: 330-331), rising to the level of value attitude towards everyone and everything. K. Marx saw this as the main prerequisite for preserving community between individuals, as well as a 'treatment' against loneliness and various forms of deviation and addiction arising from the interaction of individuals (Marx, 1961: 62). A lonely person, according to K. Marx, cannot discern himself in the Other, and therefore, cannot find one for himself.

At the initial stages of an individual's development, the dominant role in including him into the community is played by family, which represents both a community and a social institution responsible for the first stage of the individual's socialisation. It directly depends on the type of family and the nature of family relationships whether the person entering life will encounter the experience of loneliness or will pass it by, since "without exception, all human modes of activity aimed at interaction with another person and any other object, a child learns from the outside" (Il'enkov, 1984: 331). In other words, the child at the initial stages of development is completely dependent on Others. Therefore, at early age, he is likely to experience loneliness. An argument confirming the correspondence of this statement to the real state of affairs can be the fact revealed by $\mathrm{Z}$. Freud: the first phobias that children get are the phobias of darkness and loneliness (Miiuskevich, 1989: 62). The reason for this is, presumably, in the child's love and emotional closeness to his parents (especially his mother), who are Significant Others for him, and therefore to all adults who, de facto, personify accessible fragments of existence for him.

Let us note that the successful development of a child, the formation of his consciousness, self-awareness and inner world as a whole depends on his significance for Others and, over time, their significance for him. Loss of community at early age, involuntary stay outside its limits due to prevailing objective circumstances in the process of spiritual and personal development leads children to experience loneliness in an acute, painful form. For example, children with broken lives, in particular, abandoned by their parents at early age. The experience of loneliness at early age either suspends the formation of a harmonious spiritual and personal integrity of a person, or it can significantly deform it, that is, prevent a person in the future from fully revealing in himself and developing his spiritual and personal potential.

Along with the family, primary social groups (classmates, friends, etc.) have a decisive influence on the formation of an integral spiritual and personal image of a child, especially one in adolescence. They can create both favourable conditions for the socialisation of individuals, as well as unfavourable ones. The emergence of the latter is due to a whole complex of interrelated factors, which include: the erosion of the value foundations of family relations, the incompleteness of the family or its disintegration, material distress, a painful spiritual and psychological climate in the family, inattention of parents to the problems of the child due to the preference of their own interests (career, health, entertainment), the child's inability to find a common language with peers, lack of community of interests with them, and much more. Each of them is a microfactor that charts certain paths to loneliness. However, under certain conditions, any of these microfactors can develop and acquire a macrofactural structure, which will become the basis for the person's experience of loneliness in adolescence. 
G.M. Tikhonov notes the high variability of loneliness among young people (Tikhonov, 2005). This can be explained not only by socio-cultural factors, the objective nature of which is undeniable, but also by subjective-personal factors (low self-esteem, social immaturity, moral instability, self-doubt, apathy, timidity, sense of meaninglessness, etc.) (Tikhonov, 2005). Therefore, young people are ranked among weak social groups, very often prone to loneliness and vulnerable to social shocks and crises that significantly affect the spiritual and mental state of a person.

Adolescents and young adults often exhibit addictive and deviant behaviour, which can be caused by various socio-cultural and personal factors. In this case, that is, when other people lose their significance and value for a person, degradation of the personal structures of his integrity occurs along with the emergence of various forms of addictive and deviant behaviour, which is a direct path to loneliness. Quite indicative are the words said by people with addictive behaviour cited by Ts.P. Korolenko and T.A. Donskikh in the book "Seven Ways to Disaster. Destructive Behaviour in the Modern World". Here is one of examples, "I feel embarrassed and even ashamed in front of my loved ones, who do not see, do not understand that I am not the person I used to be. Some part of me remains the same, but on the whole I have changed, I have become alienated and indifferent to the feelings and sufferings of my loved ones" (Korolenko, Donskikh, 1991: 24). Addictive behaviour accompanies the ambivalence of a person's consciousness into a proper and real self and a false and unworthy Other inside me, diverting me from the Others, leading to loneliness. Deviant behaviour is a type of orientation at the expense of the Other, which ultimately leads to being without Others, i.e. loneliness, which can find its extreme form expressed in the state of existence in oblivion (full type of loneliness).

It is noteworthy that young people with deviant and addictive behaviour, who have not changed and do not want to change the way of life that has become habitual, may never properly engage in normal social life, i.e. they may not go through the stages of integration and work activity, which play a decisive role at the stage of maturity. A situation of this kind is usually typical for some young people exposed to the influence of subcultures that initiate the emergence and maintain the existence of temporary 'communities', which are based not on the relationship between one's Self and the Significant Other, but the relationship between one's Self and the Other as Myself (inauthentic Significant Other). At the same time, all other individuals who do not have signs of belonging to this subculture are not recognised. Otherness and individuality in the subculture are denied by their kind. Falling out of the boundaries of a subculture leads to a crisis, a temporary loss of meaningfulness, a feeling of alienation from the surrounding world and loneliness. A similar outcome can be associated with the de-actualisation of the subculture in socio-cultural reality, and with its replacement by some other subculture. The same and quite obvious outcome will appear in the case of young people's involvement in subcultures that turn them against other members of society.

\section{Maturity as a critical stage of development of an individual}

Maturity as a period in a person's life is important not only due to its relatively long duration (30-40 years if we follow the concept of E. Erickson), but also (again according to E. Erickson) due to the fact that it contains the peak of man's social and creative activities ensuring his integration into the social environment and closeness with other members of society, i.e. his willingness to "merge their identity with the identity of others (Erikson, 2000: 252). A person at this age 'learns' to take care of the Other and to be responsible. Undoubtedly, the age period can be considered the key one in all plans, since the features of the final stage of human development - old age characterised by summing up the results of all life lived - depend on it. E. Erickson emphasises that "fashionable persistence in exaggerating the dependence of children on adults often hinders from us the dependence of the older generation on the younger one. A mature person needs to be needed, and maturity needs stimulation and encouragement from those whom it has giv- 
en birth to and whom it should take care of" (Erikson, 2000: 255). In our opinion, the German-American psychologist is right about this; an individual who has not done anything for the people around him, who is accustomed to taking care only of himself, at the end of his life turns out to be spiritually insolvent, personally inconsistent and lonely, experiencing a feeling of hopelessness and uselessness of the past years. He comes to understand the irreplaceability of the lost, the impossibility of correcting the mistakes made in the past and regret about the meaninglessness of the ending life. But what does a person who finds himself in such a situation really regret? Surely, among his regrets is that he did not meet a Significant Other for himself on his way.

However, old age does not mean that loneliness is inevitable. On the contrary, many older people are closely connected with their family members and actively participate in social life, as they feel their responsibility for the lives of future generations. They acutely feel closeness, community with Others. Of course, the level of health plays a very important role at this age as it influences the ability of carrying out social and educational activities.

Further, it makes sense to pay attention to the fact that the mature stage of human development is critical, transitional and especially sensitive to changes in society. For this reason, mature people tend to be lonely. It is no coincidence that E. Erickson speaks about the most severe age crisis of a person, which occurs at the age of about 40 years. It is worth noting, however, that all transitional ages are quite rightly considered vulnerable human states, within which the spiritual and personal components of his integrity are unstable and subject to transformation. Therefore, loneliness often accompanies crises generated by the transition of a person from one age to another. Age crises are caused both by socio-cultural changes in society and by spiritual and psychological factors in the formation of a personality. These crises also largely depend on the social and spiritual age of an individual, i.e. on the level of his social and spiritual achievements, approving him in value-semantic orientations, linking him to certain activities and deepening his integration with other individuals. Therefore, this allows to come up with a pattern: the deeper the integration (that is, an increase in the level of community) of a person with each passed age stage the less he is prone to loneliness, and, therefore, his being is more integral, harmonious and full.

It should also be emphasised that the stage of maturity is basically the process of labour integration, when a person takes root in socio-cultural reality through his work. Taking this circumstance into account allows us to understand the reason why people at a given age are especially vulnerable to loneliness and experience it in an acute form. The middle age, which is maturity, is characterised by the borderline position of an individual, when much, which until recently was the 'firm' foundation of his life, sometimes collapses overnight, crossing out further life prospects, making the plans impossible to fulfill. Thus, the connection between the past, present and future is interrupted, which contributes to the consolidation of a person in 'timelessness' and uncertainty. Important, really influential factors at this stage can become, especially within the framework of market relations, the deterioration of the general socio-economic situation in the country and an increase in the unemployment rate, as well as political and social revolutions. The latter lead to significant system shifts in the structural organisation of society, a comprehensive restructuring of relations between individuals on new socio-economic and socio-cultural foundations. Moreover, such transformations have a particularly strong effect on the unprotected segments of the population and weak groups (the elderly, the disabled, etc.); often they become sufficient grounds for the emergence of loneliness among representatives of these strata and groups.

When these systemic and structural shifts unfold, society is plunged into an anomical state, i.e. into a state of value and normative crisis (Pokrovskii, Ivanchenko, 2008: 10). At the same time, the social system is characterised by a low degree of social 'cohesion' and the relativity of socio-cultural values and norms that have lost the status of universal- 
ity and obligation for individuals with a simultaneous loss of their regulatory power, as a result of which they cease to be a 'fetish' (Sorokin, 1992: 168-170). The current state of Russian society, the attribute of which is "disorientation of the social functions of culture, a shift in priorities and value orientations" (Koptseva et al., 2012), is difficult not to recognise as anomical.

Such systemic and structural shifts are a powerful generator of alienation processes in society and determine the deformation of the former foundations of socio-cultural reality, which cease to be something internally justified for individuals. As a result, we observe the spread of loneliness or an increase in the level of self-destruction in society due to the filling of "social space with deviant values" (Pokrovskii, Ivanchenko, 2008: 10).

Based on the foregoing, it makes sense to outline three groups of socio-cultural factors that contribute to the emergence of loneliness:

- microfactors (family, peers, friends, etc.);

- mesofactors (socio-cultural conditions, social groups, subcultures, etc.);

- macrofactors connected with largescale social processes and events;

\section{Loneliness as a result}

of the lost balance between

\section{the variables of K. Marx's formula}

The necessity for a person to constantly create conditions for his own life support (social, cultural, technical, etc.) in the process of object-oriented activity presupposes going beyond himself (fulfillment of his essence outside himself). The product produced by a person in the course of object-oriented activity and serving as a proof of the assertion of his essence allows not only to overcome his uniqueness, but also to consider him as a historical being (K. Marx) It is this moment that becomes the starting point of the Meeting of the Self and the Significant Other, giving rise to a common value-semantic world that they accept, through which not only the Self and the Other turn out to be significant for each other, but the content of this world around which they unite also acquires significance for each one of them.
Essential components of conscious transformational activity, which include culturally significant values and meanings, become an internal property of the person himself, inseparable from his being. Therefore, even the outcomes of spiritual activity must receive approval by the Other. By legitimising the processes and results of material, practical and spiritual exploration of nature through involvement, the Other himself acquires significance for the Self.

Herewith, on the one hand, nature is the subject of human activity to satisfy his needs, affirming his life, on the other hand, it turns into objectivity, man's other being, becoming the internal content of socio-cultural processes, thereby ensuring the stability of connections and relationships between participants in object-oriented activities. Being the basis of connections between individuals nature acquires a certain value and significance in them and through them. Let us clarify this idea. Nature turns out to be a value for a person not as it is, but being mediated by the socio-cultural context, as a carrier of the function of connecting it with other people (Marx, 1956: 589-590). Consequently, the relationship between man and man in the process of transformative activity, which determines his attitude to nature, and hence his involvement in interhuman relations, can be recognised as the main semantic component of his inherent internal value-semantic world. For example, if utilitarian-pragmatic relations prevail in society, which is a clear indicator of a low level of development of spiritual culture, then, accordingly, people will consider nature only as something external, as an object of exploitation, and not as the direct basis of their own life and activities. The fact of the mass enslavement of people by the processes of externalisation (when a person stops saying You and establishing a dialogue with nature) was noted by M. Buber, who eventually came to the disappointing conclusion about the universal cosmic homelessness of man ('unparalleled loneliness') (Buber, 1995: 38 ).

Therefore, socio-economic structure of society, alienating from individuals, "rises above them" and becomes alienated acquiring "an independent existence of social reality" (Ka- 
gan, 1988: 138). It makes sense to talk about the phenomenon of 'institutional alienation', in the presence of which impersonal social structures become full subjects of social activity. In this case, the personal component takes over the spiritual one in human integrity, completely subjugating the human nature, embodying the prevailing conditions of current social existence, limited by the present, localized outside the past and future. In other words, there is a deformation of the highest level of integrity of the person himself, decreasing the 'degree' of the spiritual and moral component, which makes it impossible for him to go beyond the established system of inter-human relations. To some extent, he himself becomes a tool for the existing social structures. As a result, the human world becomes alienated and hostile to man, while relations between people lose their truly human nature, and the man himself turns into an alienated and lonely being.

\section{Conclusion}

Despite the fact that loneliness, as we can see, is a destructive phenomenon of a person's being, which makes it difficult to expand the boundaries of his spiritual and personal integrity (incomplete loneliness) or exhaustively leads him to degradation (complete loneliness), being de facto not immanent to his being, arises at certain stages of an individual's development, which is largely due to the specifics of the present state of socio-cultural reality. The more intense the impact exerted by external (socio-cultural) factors, the faster the boundaries of the integrity of the Meeting shrink, and the faster the processes of degradation of human integrity unfold. Under the influence of socio-cultural processes, the boundaries of spiritual and personal integrity and the inner world of a person are 'compressed' to such an extent that they cease to fulfill the functions of life support.

\section{References}

Belyaev, I.A. (2011). Human Being: Integrity and Wholeness. In Journal of Siberian Federal University. Humanities \& Social Sciences, 5, 633-643.

Buber, M. (1995). Dva obraza very. Moscow, Respublika, 464 p.

Erikson, E. (2000). Detstvo i obshchestvo [Childhood and society]. Saint-Peterburg, OOO Rech', 416 p. Gert, V.A. (2016). TSelostnost' i sub 'ektivnost' individual'nogo bytiia cheloveka [Intergrity and subjectivity of individual being of a person]. Thesis of the Doctor of Philosophy, CHeliabinsk, $381 \mathrm{p}$.

Il'enkov, E.V. (1984). CHto zhe takoe lichnost'? S chego nachinaetsia lichnost' [What is Personality? What does personality start with?]. Moscow, Politizdat, 319-358.

Kagan, M.S. (1988). Mir obshcheniia: problema mezhsub'ektnykh otnoshenii [The world of communication: the problem of intersubjective relationships]. Moscow, Politizdat, $319 \mathrm{p}$.

Kogan, L.N. (1981). Vsestoronnee razvitie lichnosti i kul'tura [Comprehensive development of the personality and culture]. Moscow, Znaniye, $63 \mathrm{p}$.

Koptseva, N.P., Bakhova, N.A., Zamaraeva, J.S., Kirko, V.I. (2012). Problema sotsiokul'turnykh issledovaniy v sovremennoy gumanitarnoy nauke [The problem of socio-cultural research in modern humanities] In Sovremennyye problemy nauki i obrazovaniia [Modern problems of science and education], 3, 323-323.

Korolenko, T.S., Donskikh, T.A. (1991). Sem' putei k katastrofe. Destruktivnoe povedenie v sovremennom mire [Seven ways to a catastrophe. Destructive behaviour in the modern world]. Novosibirsk, Nauka, Sibirskoe otdelenie, $224 \mathrm{p}$.

Kuda idet rossiiskaia kul'tura? [Which way is the Russian science going?] (2016). In Voprosy filosofii [Issues of Philosophy], 9, 3-60.

Levi-Strauss, K. (1985). Strukturnaia antropologiia [Structural Anthropology]. Moscow, Glavnaia redaktsiia vostochnoi literatury, $536 \mathrm{p}$.

Lotman, Yu.M. (2002). Stat'i po semiotike kul'tury $i$ iskusstva [Articles on semiotics of culture and art]. Moscow, Akademicheskii proekt, $544 \mathrm{p}$.

Markov, B.V. (2009). Filosofskaia kontseptualizatsiia cheloveka [Philosophic concetualisation of man]. In Analitika kul'turologii [Analytics of culture studies], 15, 17-26. 
Marx, K. (1956). Iz rannikh proizvedenii [Early works]. Moscow, Gospolitizdat, 632 p.

Marx, K. (1955). Sochineniia: v 50 t [Collected works: in 50 volumes]. Moscow, Gospolitizdat, 3, 630 p.

Marx, K. (1961). Sochineniia: v $50 \mathrm{t}$ [Collected works: in 50 volumes]. Moscow, Gospolitizdat, 23, 908 p.

Marx, K. (1962). Sochineniia: v 50 t [Collected works: in 50 volumes]. Moscow, Gospolitizdat, 27, 536 p.

Miiuskevich, B. (1989). Odinochestvo: mezhdisplinarnyi podkhod [Loneliness: interdisciplinary approach]. In Labirinty odinochestva [Labirinths of loneliness]. Moscow, Progress, 52-87.

Nazaretian, A.P. (2012). Antropologiia nasiliia i kul'tura samoorganizatsii: Ocherki po evoliutsionno-istoricheskoi evoliutsii [Anthropology of violence and culture of self-organisation. Notes on historical evolution]. Moscow, LIBRIKOM publishing house, $256 \mathrm{p}$.

Pivovarov, D.V. (1996). Religioznoe samoopredelenie cheloveka v kontekste kul'tury [Religious self-determination of a person within the framework of culture]. In Filosofiia samoopredeleniia [Philosophy of self-determination]. Orenburg, 41-70.

Pokrovskii, N.E., Ivanchenko, G.V. (2008) Universum odinochestva: sotsiologicheskie i psikhologicheskie ocherki [Universum of loneliness: sociological and psychological notes]. Moscow, Logos, $424 \mathrm{p}$.

Sorokin, P.A. (1992). Chelovek. Tsivilizatsiia. Obshchestvo [Man. Civilisation. Society]. Moscow, Politizdat, $543 \mathrm{p}$.

Tönnies, F. (2002). Obshchnost' i obshchestvo. Osnovnye poniatiia chistoi sotsiologii [Community and Society. Main concepts of pure sociology]. Saint-Peterburg, Vladimir Dal', $452 \mathrm{p}$.

Tikhonov, G.M. (2005). Odinochestvo: stereotipy real'nost' [Loneliness: stereotypes and reality]. Izhevsk, IzhGTU publishing house, $374 \mathrm{p}$.

Tikhonov, G.M. (2013). Fenomen odinochestva: ekzistentsial'nyi aspect [Phenomenon of loneliness: existential aspect]. In Istoricheskie, filosofskie, politicheskie i iuridicheskie nauki, kul'turologiia iskusstvovedenie. Voprosy teorii i praktiki [Historical, philosophic, political and judicial sciences, culture studies and art history. Issues of theory and practice], 1, I, 183-186. 


\title{
Социокультурная детерминированность одиночества человека
}

\author{
И.А. Беляев, М.Н.Лященко \\ Оренбургский государственный университет \\ Российская Федеращия, Оренбург
}

\begin{abstract}
Аннотация. В статье представлено обоснование социокультурной детерминированности одиночества человека. Философско-культурологический дискурс развертывался посредством синтеза разнородных и разнохарактерных теоретических положений. Первостепенно важной для исследования явилась формула К. Маркса, согласно которой единство отношения человека с природой определяется единством отношений между индивидами. Учитывалось существование общества и общности как двух диалектически взаимосвязанных форм социальности, отсутствие согласованности между которыми способствует возникновению одиночества человека. Эвристически ценным для проведения изысканий стало положение синергетической парадигмы о неравновесном характере общественных структур. Получению искомого результата способствовала опора на информацию о возрастных особенностях развития человека, почерпнутую из концепции Э. Эриксона. Философско-культурологическая интерпретация указанных и сопряженных с ними положений позволила установить, что одиночество допустимо признать следствием понижения уровня общности во взаимодействии между индивидами и невозможности обеспечить поддержание ее высокого уровня, находящего свое выражение во Встрече Я и Значимого Другого (своего Другого). Выявлено: общность со Значимым Другим есть мера актуализации целостности и полноты бытия человека; чем разнообразнее и шире ареал Значимых Других, тем гармоничнее бытие человека; по-настоящему полноценен тот человек, который максимально расширил горизонты Встречи; повышение глубины интеграции человека с процессами и явлениями, естественными для каждой пройденной возрастной стадии, снижает для него вероятность оказаться в одиночестве, а следовательно, крепче укореняет его в бытии.
\end{abstract}

Ключевые слова: одиночество, культура, общество, общность, Встреча, целостность человека.

Научная специальность: 09.00.00 - философские науки. 